\title{
Beyond genetic discrimination. Problems and perspectives of a contested notion
}

\author{
THOMAS LEMKE
}

\begin{abstract}
In the recent past a number of empirical studies provided evidence that increasing genetic knowledge leads to new forms of exclusion, disadvantage and stigmatisation. As a consequence, many states have inaugurated special legislation to fight "genetic discrimination".

This article focuses on some theoretical, normative and practical problems in the scientific and political debate on genetic discrimination. It puts forward the thesis that the existing antidiscrimination approach is based on the implicit idea that genes are the essence of (human) life. Since genes are held responsible for individual development and personal identity, genetic discrimination is granted a privileged legal status in comparison to other forms of discrimination. As a result the analytical and political concentration on processes of genetic discrimination may reinforce the "geneticization" of body, illness and deviance.
\end{abstract}

\section{Beyond genetic discrimination. Problems and perspectives of a contested notion}

The sequencing of the human genome at the beginning of the new century marked a symbolic milestone in the progress of genetics. In the "post-genomic" era genetic research is about to transform concepts of health, illness and the body, and the practices of medicine and public health. Genetic tests already have been developed to identify the presence of particular alleles or polymorphisms that are linked to certain diseases. As the range and accuracy of these tests increase, many scholars anticipate a future when anyone may obtain genetic profile that can identify conditions for which he or she may be at elevated risk. Such knowledge should enable an individual to take preventive steps such as medication, medical monitoring, prophylactic surgery, or behavioural and environmental modification that may be wholly or partially effective to eliminating the onset of diseases. ${ }^{2}$

As with many other new technologies, the implementation of genetic technology raises a number of social problems. One area of concern is "genetic discrimination". As a series of empirical studies in different countries have shown the use of genetic information may lead to new forms of exclusion, disadvantaging and stigmatisation. ${ }^{3}$ The spectrum of genetic discrimination ranges from disadvantages in work life via problems with insurance policies through to difficulties with adoption agencies. In some cases a person was turned down for a job because there were signs of a possible later illness. Likewise, health and life insurers terminated contracts or refused to conclude these if their (potential) clients were suspected of bearing the risk of a congenital disease. In other cases, couples were not allowed to adopt children if one of the two had a predisposition for a genetic illness. Experiences of genetic discrimination were also reported from healthcare agencies, the education sector and the military. ${ }^{4}$ 
The empirical studies on the problem of genetic discrimination have not gone unnoticed. In the scholarly debate and policy discussions in society, much has been made of the danger of a "biological underclass". People who were disadvantaged, pathologised and stigmatised simply owing to their genetic structure. The fear of a "new form of social prejudice" led to numerous attempts to regulate the problem. Since the beginning of the 1990s a series of legislative initiatives and statements on the part of inter- and supranational organizations and commissions have been forthcoming to protect people from genetic discrimination. For example, the Council of Europe's Convention on Biomedicine (Art. 11), UNESCO's Declaration on the Human Genome (Art. 6), and the EU's Charter on Fundamental Rights (Art. 21) all explicitly prohibit discrimination on the basis of genetic features. Likewise, many nations have issued regulations designed to ensure that no one is disadvantaged on the basis of his or her genetic constitution. Thus, in some countries, including Austria and Belgium, genetic discrimination is in principle forbidden. In the United States, special laws were resolved at an early date by individual states of the Union and by the federal government. In Germany, among others, there is currently discussion on additional legal initiatives to protect against genetic discrimination.

However, it has since become ever more apparent that the concept of genetic discrimination, as is used in scholarly studies and in legal texts, entails various theoretical, normative and practical difficulties. I wish in this essay to address in greater depth four problematic areas that reveal significant gaps or weaknesses in the debate on genetic discrimination: Discrepancies in the use of the concept of discrimination in research practice (1); empirical shortcomings that mean central areas of genetic discrimination are not covered (2); conceptual problems in defining the special scientific status of genetic information (3); and finally normative ambivalences as the notion that genetic data should be subject to a more comprehensive protection compared with non-genetic information leads to unjustified unequal treatment of persons affected (4). The central argument I shall advance is that the theoretical and political-legal critique of practices of genetic discrimination frequently itself rests on the implicit notion that genes fundamentally influence human existence and form the core of our respective personalities. I suspect that this critique covertly relies on an essentialist concept of a genetic program that is deemed responsible for individual development and personal identity. In summary I shall present some conclusions drawn from this observation with regard to further scholarly and political discussion on genetic discrimination (5).

\section{Definitional discrepancies: scope and content of genetic discrimination}

In the scholarly literature and also in the media and the relevant laws genetic discrimination signifies the unequal treatment of people owing to actual or suspected genetic differences from the "normal" genome. Here, genetic discrimination is strictly distinguished from discrimination owing to a disability or illness. ${ }^{7}$ All the relevant empirical studies rely on this definition of genetic discrimination, but the application of it in research practice has varied greatly - something that undermines the comparability of research findings. 
Lapham et al. use a very broad concept of discrimination for their work; it includes not only presymptomatic cases, but also cases in which the persons in question have already fallen ill. ${ }^{8}$ As a result, phenotypical and genotypical characteristics are both used as the basis for defining the presence of genetic discrimination. ${ }^{9}$ Most other studies seek only to speak of genetic discrimination against the persons concerned if the symptoms of the illness are very mild or do not constitute a disability or restriction in performance. ${ }^{10}$ By contrast, an extremely narrow concept of discrimination is utilized by Mark A. Hall and Stephen S. Rich in their study, as they only take into account cases in which the persons concerned were completely presymptomatic, in other words in which the illness was in no manner manifest yet. The different concepts of discrimination lead to contrary findings: While Hall and Rich had difficulty documenting even a single case of genetic discrimination, the study by Lapham et al. states that almost half of those polled had experienced genetic discrimination. ${ }^{11}$

Not just the scope, but also the substance of the concept of discrimination is a bone of scholarly contention. In the relevant studies, genetic discrimination is regularly construed as the "unjustified unequal treatment of persons owing to their genetic characteristics". ${ }^{12}$ The literature usually takes a critical perspective: The implicit assumption is that unequal treatment owing to factual or suspected genetic differences is legally impermissible and/or morally objectionable. However, in addition to this majority view, there are other opinions that consider genetic discrimination a factually legitimate form of risk differentiation. ${ }^{13}$ An extreme position in this regard is taken in the libertarian argument advanced by Colin S. Diver and Jane Maslow Cohen. They contend that the unequal treatment of human beings owing to genetic factors is not only morally unproblematic and legally permissible, but also socially necessary as an economic instrument of resource allocation and risk calculation. From this standpoint, government prohibitions on genetic discrimination prevent the efficient market regulation that requires a "regime of genetic transparency". ${ }^{14}$

Needless to say, the conceptual discrepancies are not only of interest as regards research strategies and at the theoretical level, but are of great significance for legislative practice and social policy: Is genetic discrimination a legitimate means of risk differentiation in order to generate economic growth and prosperity or a social evil that calls for corresponding government measures to protect persons from it? And if the latter is the case, what individuals and groups with what illnesses and/or risks of illness should be protected against discrimination, and in what way? How broad or narrow should the circle of those be who are to benefit from legal protection?

\section{Empirical deficits: "Everyday eugenics" and indirect discrimination}

The studies to date that deal with the problem of genetic discrimination have a clear emphasis. They concentrate on institutional actors disadvantaging individuals and their relatives. This analytical focus means that important practical areas of genetic discrimination do not get equal attention. I shall scrutinize two empirical deficits more closely here: the focus on institutional actors and the neglect of indirect forms of discrimination. ${ }^{15}$ 


\subsection{Focus on institutional actors and asymmetric decision-making}

So far studies of genetic discrimination mainly focused on institutional actors, on the one hand, and individuals and relatives, on the other. This juxtaposition is too strongly entrenched in the juridical frame of committer/victim. However correct and important it may be to expose discriminating practices by insurance companies, employers, adoption agencies and other organizations, this disregards a decisive arena of genetic discrimination: disrespect and stigmatisation by family, friends and fellow human beings. This "everyday discrimination" is systematically ignored in the studies to date, meaning a key field of genetic discrimination remains excluded.

In addition to this analytical gap there is another problem: Literature on genetic discrimination tends to concentrate on the "negative" pattern of litigation: on coercive measures and asymmetric decision-making processes. The guiding idea here relates to organizations that refuse to sign contracts or reject qualifications. Thus, the studies exclude to investigate to what extent formally voluntary options for action and symmetrical decision-making situations can have a discriminating effect. A core element of the new genetic knowledge consists precisely of the fact that it transforms natural constrains into new individual options - options that may engender new constrains. Scholars discern a transition from a compulsory eugenics to a more indirect form of control and guidance of individuals, something the academic debate has termed "voluntary"16 "individualist"17, "liberal"18 or "everyday eugenics" Those critical accounts point to the fact that individual decisions and private choices may, taken collectively, have negative social effects and create new pressures on reproductive behaviour. While some scholars resist the idea that human genetics represents a disguised or a new kind of eugenics, the question remains whether the phenomenon of genetic discrimination is restricted to explicit prohibitions and rare exceptions, or may also result from "normal" risk assessments, "rational" concepts of health and the idea of a "self-regulative behavioural management". 20

\subsection{Neglect of indirect mechanisms and structural links}

This conceptual problem points to the limits of a person-centred and case-oriented notion of discrimination. Alongside discrimination of people who are directly confronted by disadvantaging or stigmatisation, forms of "indirect" discrimination must also be considered. This should include all factors that indirectly influence the persons involved and constrain their scope for decision-making and their options for action. While direct genetic discrimination remains a matter of individual cases and describes the way in which certain people with genetic characteristics are treated as individuals, indirect discrimination refers to social judgments of unworthiness, structures of prejudice and forms of disrespect addressed to all members of society. ${ }^{21}$

A comprehensive analysis of genetic discrimination must also focus on those strategies for action with which the persons affected anticipate negative categorization by their social environment and adapt their behaviour accordingly. The most effective means of pre-empting genetic discrimination entails not drawing genetic risks to the attention of other people, let alone institutional actors such as insurance companies or employers. This "information control" runs from the choice of spouse via neighbourly relations to working life. The persons affected feel the act of excluding their own risk 
of falling ill and the related fears as a form of compulsion, as a restriction in forms of communication, and as the necessity to keep important information on themselves and their own future secret from others. ${ }^{22}$

Moreover, the judgment on unworthiness as is expressed in practices of genetic discrimination, also impacts on decisions on reproduction that go far beyond the realm of those who are directly affected by the risk of genetic illness. While studies on the problem of genetic discrimination to date have concentrated on postnatal genetic tests and the disadvantaging of persons already born, it bears asking whether the analysis should not also cover the field of prenatal diagnostics (selective abortion on the basis of genetic indicators) and pre-implantation diagnostics (deliberate choice of genetically "desired" embryos). ${ }^{23}$

But it does not suffice for a systematic analysis of genetic discrimination to simply internally differentiate between various practices of genetic discrimination. We must also consider the "structural links" between different forms of discrimination. In this way, we can study how forms of genetic discrimination link up with sexist and racist practices and mutually reinforce one another. ${ }^{24}$

As regards the relationship of genetic discrimination and racism, it bears stating that some genetic illnesses are encountered more frequently in certain ethnic groups or groups of the population than in others. For example, sickle cell anemia occurs more frequently among persons of African descent, Tay-Sachs Syndrome is especially widespread among Ashkenazi Jews, and most persons with the beta thalassemia gene are inhabitants of the Mediterranean rim. Since certain ethnic groups are differently susceptible to specific genetic illnesses, there is a danger that members of minorities will be associated with such genes and treated pathologically, even if they do not bear the particular genetic mutation. For example, sickle-cell anemia in the United States is considered a disease of Afro-Americans, although it is to be found just as frequently among population groups from the Mediterranean rim. ${ }^{25}$ There is likewise the danger that there will be a disparity in resource allocation and in the public attention on these diseases. For example, in the USA research into cystic fibrosis, which affects primarily white coloured people, receives far more financial backing than does research into sickle cell anemia, even if the latter is far more widespread among the population as a whole. ${ }^{26}$

The practice of gender verification at sports competitions is a striking example of the linking of genetic discrimination und sexism. Gender control by genetic testing emerged as an issue in the 1960s when there were rumours that men had passed themselves off as women to take part in women's competitions. Despite the intensive criticism down through the years, genetic analyses are still undertaken to verify gender in sport. However, only women and not men have to have their gender verified, and suffer the possible consequences of "failing" such a test. Although almost all International Olympic Committees now forego such verification procedures, at world championships for some sports gender continues to be genetically "tested". For example, at the Volleyball World Championship in 2002 in Germany, all the women were subjected to a genetic analysis if they did not have test results from a prior sports competition. ${ }^{27}$ 
A person-centred and case-oriented concept of discrimination is not able to explore the systematic links between racist and sexist practices and ideologies on the one hand, and patterns of geneticist interpretation and action, on the other. Genetic discrimination does not entail isolated and chance deviations from the norm, individual cases and erroneous institutional developments, but it points to social practices that divide persons into genetic categories and promote a belief in the determining power of genes. ${ }^{28}$ Unfortunately notions of genetic essentialism frequently also shape the analysis and critique of genetic discrimination, leading to conceptual confusion on the one hand and normative ambivalences on the other.

\section{Conceptual confusions: the exceptional epistemological status of genetic information}

Studies on genetic discrimination and legislative initiatives to protect affected persons share a common presumption: both assume an exceptional status of genetic information in two ways. ${ }^{29}$ First, there is the claim that genetic information differs epistemologically from non-genetic information. From this perspective there is a clear scientific line dividing genetic testing from non-genetic procedures, genetic diseases from non-genetic conditions. Second, there is the suggestion that genetic information should be normatively distinguished from non-genetic information: discrimination on the basis of genetic data on the current or future health of a person is then unjust or more unjust compared to discrimination on the basis of non-genetic medical information. As I shall attempt to show, both assumptions are untenable. I shall focus in this section on the justifications for an exceptional epistemological status of genetic information, and then in the next section trace the normative problems to which this gives rise.

\subsection{Genetic exceptionalism}

There are at least three arguments put forward to justify the exceptional (medical) position of genetic screening. Genetic analytical procedures are claimed to be more precise than other medical tests as they provide predictive information on the health of an individual. They are said to allow it to diagnose with certainty or greater probability whether a person will fall ill with a specific disease. Second, the results of genetic tests are said to enable conclusions to be drawn on the state of health or risk of illness of relatives of the person screened. Genetic tests are, thirdly, believed to differ from traditional diagnostic techniques and conventional medical methodologies, as they purportedly reveal fundamental personal characteristics of the person examined. All three criteria thus used to justify "genetic exceptionalism" do not stand up to closer scrutiny. ${ }^{30}$

First, only a very few genetic tests allow predictive statements to be made on future illnesses. Genetic illnesses are as a rule characterized by incomplete penetration and/or variable expressivity. ${ }^{31}$ The former relates to the frequency with which genetic mutation actually trigger the corresponding disease in the person bearing the gene. In the case of complex illnesses such as cancer, Alzheimer's or diabetes the presence of a changed gene does not necessarily lead to illness. For example, proof of a mutation of one of the so-called BRCA genes increases the statistical probability of a woman developing breast cancer, but the question whether, when and in what way she 
succumbs to the illness is by no means answered. ${ }^{32}$ As recent studies have shown, even monogenetic illnesses such as cystic fibrosis or Morbus Huntington do not entail $100 \%$ penetration. $^{33}$

Variable expressivity refers to the fact that the symptoms of one and the same illness can differ vastly from one individual to the next, although both possess the same mutated gene. In other words, the same DNA mutation can trigger quite different clinical symptoms - or none at all; conversely, one and the same disease can be triggered by different genetic variations. ${ }^{34}$ It bears stating here not only that the predictive value of genetic information is regularly exaggerated, but also that nongenetic medical tests provide information on future health risks, such as a HIV test, a cholesterol screen, or the proof of an asymptomatic hepatitis B infection. Likewise, blood-pressure tests or proof of blood in stool are of great diagnostic importance when identifying illnesses at an early stage before the first symptoms of coronary heart disease or stomach cancer have arisen. ${ }^{35}$

As regards the second criterion, it is also difficult to recognize the medical uniqueness or even the special status of genetic analyses. As Murray rightly emphasizes, people have long since known that their own risk of having an illness increases if the same illness has already arisen in their family. Likewise, in the past, doctors have relied on information on relatives to supplement their medical knowledge on a particular patient. Moreover, a person's family history has for some time been factored into insurance contracts and/or consulted when defining premiums. Genetic tests are, in other words, neither the only nor the most important tools for using medical data on relatives in order to reach statements on an individual's health status. ${ }^{36}$

The third criterion differentiates between a fateful and immutable genetic predisposition, on the one hand, and chance and controllable environmental factors, on the other. This argument rests on the notion that genes are autonomous and active, forming a kind of control centre that steers and regulates the organism. ${ }^{37}$ This assumption is at best a vast simplification if not misleading or false. First, genes are not static units, but an integral part of a complicated biochemical network that is defined by the dynamic interaction of interdependent actors. ${ }^{38}$ For this reason, it is an impermissible simplification if we assume that a characteristic or function is determined in part by heredity and otherwise by environmental influences. This fails to consider that genetic changes can also be first acquired in the course of life owing to environmental influences and a specific life style. ${ }^{39}$ Furthermore, there can be no simple equation between genetic causality and an inevitable fate and/or non-genetic factors and personal scope to take free decisions. Neither do genetic causes of illness signal a necessary biological fate, nor are non-genetic conditions in principle easier to control than their genetic counterparts or the result of personal choices for which the individual is responsible. ${ }^{40}$ On the contrary, there are also many non-genetic factors which we as individuals can by no means control: "If the air we breathe and the water we drink are polluted, if our parents or co-workers are heavy smokers, if we are reasonably prudent but injured in an accident nonetheless, it is hard to say that we bear any significant measure of responsibility for the resulting illness". 41 
All the three criteria that ostensibly justify the special (medical) position of genetic information discussed here thus prove unconvincing. That said, not only is the line dividing genetic from non-genetic factors is diffuse, but also it is not clear what exactly "genetic" means. Put differently: What we have here is thus not a definitional problem that results from an impermissible conflation or erroneous shift of the line dividing two essentially distinguishable components (genetic/non-genetic); instead, it is a systematic problem that lies in the "nature" of the matter at hand. What is respectively termed a "gene" or "genetic" entails great semantic flexibility and depends on the respective scientific definition and social context. ${ }^{42}$

\subsection{Genetic or non-genetic?}

The concept of genetic illness has been constantly expanded in recent decades. Today, genetic factors are considered to be responsible not only for "monogenetic" illnesses (so-called congenital illnesses), but also for multifactored diseases such as cancer, Alzheimer's, diabetes and many other widely-spread illnesses. This semantic expansion has gone hand in hand with a shift in meaning such that illnesses are increasingly construed as genetic deviations from the norm. However: If every illness can potentially be ascribed to genetic changes, it becomes questionable what exactly the contribution made by genetic factors is and/or how genetic causes of illnesses are to be distinguished from their non-genetic counterparts. ${ }^{43}$

It is not only impossible to finally and definitively state what distinguishes a genetic illness from a non-genetic complaint; it is likewise unclear how genetic analyses can be distinguished sharply from non-genetic analyses. "Genetic diagnostics" is the umbrella term used to cover all types of diagnosis of genetically determined illnesses and features. This includes tests at the level of DNA as well as phenotypical diagnoses (such as the test for genetically conditioned colour blindness), chromosome examinations and analyses at the level of genetic products. ${ }^{44}$

Joseph S. Alper and Jon Beckwith rightly point out that this comprehensive definition of genetic tests applies to practically all clinical test procedures. They emphasize that most medical tests focus on diagnosing abnormal concentrations of biochemical units. Typically, these units are proteins that are generated directly by genes, or molecules whose synthesis depends to a more or less large degree on the activity of the genes. Which is why a striking biochemical finding can be the result of a changed gene or genotype. Even if these non-genetic tests focus on determining the function of the various organs, they possibly also provide information on genetic characteristics. In addition, in some cases only the medical context can decide whether a genetic or a non-genetic test is involved: "A test of blood cholesterol concentration may be regarded as genetic when testing an individual with a family history of hypercholesterolemia, a single gene recessive disorder. The same test is clearly a nongenetic medical test when ordered in the course of a routine physical examination. $" 45$

It follows that genetic diseases cannot be exclusively detected by means of genetic testing (or, to be more precise, DNA diagnostics). In many cases, conventional screening procedures can reliably prove the existence of a genetic condition. The fact that a distinction between genetic and other diagnostic devices is not merely a technical matter can be seen from the history of the PKU screening as reconstructed 
by Diane Paul. PKU is a metabolic illness where an enzyme defect prevents the amino-acid phenylalanine being transformed into tyrosine. However, initiating a special diet when the patient is still a child can largely offset this problem. When, in the 1960s, the so-called Guthrie Test was developed and used as a diagnostic tool with newborn infants, the genetic dimension of the disease played no role; instead, back then PKU was considered a treatable form of mental retardation. Moreover, the method used to prove its existence is a biochemical test, not DNA-level screening. Only much later did the Guthrie Test come to be regarded as a genetic test and PKU as a genetic condition - a label that served various interests at the same time. The molecular medicine visionaries were able to point to the PKU Test to demonstrate that genetic tests exist that does provide a therapeutic benefit. That said, critics of genetic screening also profited from the label "genetic test". In the framework of the Human Genome Project, commissions were set up in the United States and various other countries to specifically regulate genetic analyses (in contrast to other medical tests). Since genetic screening requires greater technical care and more intensive legal regulation than do other methods, the definition of the PKU Test as a genetic test was also of interest to critics of genetic determinism who are sceptical of the increasing use of genetic screening. ${ }^{46}$

It is obviously not only difficult to distinguish with any scientific precision between genetic and non-genetic diseases. Moreover, the dividing line between genetic and non-genetic tests can also not be defined intrinsically in technical terms. As we saw, in the final instance the difference is the product of social negotiations and scientific compromises. This insight has a strong impact on political initiatives that endeavour to regulate the use of genetic data by means of special anti-discrimination legislation.

\section{Normative ambivalences: the legal privilege of genetic information}

Discrimination on the basis of genetic factors is directed against "asymptomatic ill persons" 47 , while discrimination of ill and disabled persons results in unequal treatment on the basis of phenotypic features. Generally, the former is considered more problematic in moral and legal terms than the latter, which leads to a asymmetrical treatment of those suffering from discriminatory practices. First, genetic and non-genetic discrimination are treated differently in legal terms, which prompts the question what criteria are used to justify such an unequal treatment of persons who are equally affected by discriminatory practices. Second, there is the danger that the exceptional legal status of genetic discrimination simply "normalizes" all non-genetic forms of discrimination. If in the widest variety of different social areas the disabled and the ill are regularly discriminated against compared with the healthy, then this appears legitimate to the extent special protection exists for persons who are affected by practices of genetic discrimination. ${ }^{48}$ Put differently: the concentration on the legal impermissibility and moral reprehensibility of genetic discrimination isolates different forms of discrimination, plays them off against one another, and threatens to augment the social acceptance of practices of non-genetic discrimination.

Gregor Wolbring has pointed out that in principle two completely different strategies for legal policy are conceivable in order to prevent discrimination against asymptomatic ill persons. The one path could be to extend and expand existing antidiscrimination legislation on the equal treatment of the disabled such that it equally 
covers discrimination against the asymptomatic and symptomatic, the genetic and the non-genetic ill. However, at present a quite different approach is being taken in the United States and many other countries that envisage special laws to protect the asymptomatic ill. The laws or legislative projects currently being negotiated are based on a strict and unequivocal distinction between the asymptomatic and symptomatic ill. Wolbring points out that this serves to increase the legal gap between the two groups of persons affected. Instead of grasping genetic discrimination as an integral part of a social continuum of discriminatory practices, it is considered as a specific caesura to be distinguished in conceptual and normative terms from other forms of disadvantaging. As Wolbring rightly remarks, it is however questionable whether discrimination against the asymptomatic ill would exist without discrimination against the symptomatic ill and the disabled. ${ }^{49}$

Strikingly, there are differences in the legal and moral appraisal not only as regards the symptomatic as opposed to asymptomatic ill, but also within the group of the asymptomatic ill. A distinction is made there between persons affected by genetic risks and those exposed to non-genetic risks of illness. Both sections of the group share the fact that the illness is not yet developed, and will possibly never do so, but the legal evaluation of the risks is completely different. The problem is perhaps best illustrated by juxtaposing two similar cases that were decided almost simultaneously in the same federal state of Germany.

\section{1. "From the cradle" - The rebirth of genetic essentialism as anti discrimination policy}

The first case was recently taken up by various media and found a lot of attention inside and outside Germany. ${ }^{50}$ In August 2003, the State of Hessen refused to employ a teacher as a civil servant after she had completed her trial period. The enquiry by the officially appointed occupational physician had revealed that the young woman's father suffered from Huntington's Disease. ${ }^{51}$ The report came to the conclusion that at the present point in time the applicant's health was suitable to enable her to take up the job, but she was barred from becoming a civil servant on the ground that there was an increased probability that she would fall ill in the foreseeable future and become enduringly unfit to discharge her duties. The applicant lodged an appeal against this decision before the Administrative Court in Darmstadt, which ruled mainly in her favour and instructed the State of Hessen to immediately appoint her to government service. In the court's opinion, the school authorities had wrongly assessed the state of her health as an applicant, as they had claimed that the 50-percent risk of illness meant there was a "most strong probability" she would enduringly not be able to discharge her duties. The school board declined to contest the decision and has since employed the woman in question under a government service contract. ${ }^{52}$

At the same time, another case was before the courts but attracted far less public attention. Again in Hessen, a young man was dismissed while still on probation for government service, as in the opinion of his employers given his weight of $120 \mathrm{~kg}$ his health was not suited for a career in general administration. Here again the applicant took the matter before the courts. However, in its ruling the Frankfurt Administrative Court confirmed that the dismissal was legal as the employer was permitted to preempt the risk of having to foot the bill for later enduring damage to the man's health. ${ }^{53}$ 
In other words, although the applicant was not yet ill and it is completely uncertain whether and in what way his elevated body weight might impair his health in the future he was treated in legal terms as though he were already incapable of pursuing his duties.

These examples show that the distinction between genetic and non-genetic information cannot serve as the basis for legal differentiation. First, it is not intelligible why, for example, the use of biochemical methods that allow making inferences on a person's genetic disposition is permissible for discriminatory purposes, while DNA tests, that reach the same results, are forbidden. It would seem not only fairly impractical but also unfair to prohibit an insurance company from evaluating a genetic analysis for a complex disease, while the results of a non-genetic test for the same illness may be relied on. This methodology essentially creates a legal situation in which people with positive genetic diagnoses receive more protection against discrimination and data abuse than those whose findings are based on nongenetic methods: "Would the law mean that the records of a person with a presymptomatic heart condition who was given a genetic test for some mutant gene associated with heart disease would be covered by anti-discrimination provisions, but not the records of a person with the same condition whose physician order only nongenetic tests?",54

Second, it remains unclear why institutional actors such as insurance companies or employers should be forbidden from using $a$ source of genetic information (genetic screening) although they are allowed to draw on other forms of genetic knowledge. For example, according to a draft by the German Health Ministry for a bill on genetic diagnostics, an insurance company would be prohibited from demanding that a woman who a BRCA test shows as positive for breast cancer pay a higher insurance premium, whereas this is permissible with regard to a woman who has preferred not to undergo genetic screening but in whose family several women have already had breast cancer. ${ }^{55}$ This asymmetric decision-making principle not only violates the principle of fairness, but also means we must fear that such a regulation will compel people to opt for genetic analyses even if they did not originally want to - for example, in order to get insurance policies (at standard conditions). ${ }^{56}$

Third, the increasing discovery of genetic factors for the genesis of illnesses will in future make it ever harder to draw a line between genetic and non-genetic conditions. With reference to the above-mentioned case, a series of research findings could be cited, for example, that point to a genetic component in obesity. ${ }^{57}$ What would the judgment be if an applicant could credibly claim that a specific genetic disposition is (co-) responsible for his increased body weight? Would we then be confronted by a case of genetic discrimination and would need to specially protect those concerned from it?

To summarize, we can say that the emphasis of anti-discrimination policies is evidently more on the (genetic) "nature" of information and less on social practices in which these data are used and evaluated. ${ }^{58}$ The legislation to protect against genetic discrimination are not least the product of the implicit notion that genes fundamentally influence human existence and constitute the core of each personality. It is accordingly unfair to punish persons for something that they cannot themselves 
control. ${ }^{59}$ This logic is also to be found in the justifications given by the German Health Ministry for the planned legislation on genetic diagnostics. The statement in question says that any form of genetic discrimination must be countered: "For our genetic characteristics 'are with us in the cradle' and we are therefore not responsible for them". ${ }^{60}$ This argument may initially seem plausible, but on closer inspection is not very convincing, as it is based on the idea of a genetic program that is "responsible" for the development and identity of individuals and that both constitutes and constraints their scope for action. It is the assumption of a particular power and autonomy of genetic factors that forms the basis for their privileged legal status. In principle, there are many non-genetic factors that are just as little susceptible to personal control although we do not call for them to be specifically protected. It is by no means evident why a person whose higher risk of contracting a specific type of cancer, say, is attributable to genetic factors, should enjoy greater protection than some one whose health is threatened by environmental factors such as poor working conditions or polluted air. Should not this group of persons likewise be effectively protected ${ }^{61}$

We can assume that the explicit withdrawal of responsibility in the case of genetic risks of illness is the other side of the coin of an increasing ascription of responsibility for all non-genetic factors. ${ }^{62}$ The reductionist concept of genetic fatalism that purportedly unravel automatically and independently of the individual person's will contrasts with the radicalized appeal to personal responsibility and personal accountability as regards health and the prevention of illness. ${ }^{63}$ Possibly, the different judgments in the two afore-mentioned cases stem from a shared underlying logic that places the question of personal responsibility at the centre of things. Increased body weight and the resulting risks to a person's health are essentially considered the (erroneous) result of individual choice, while the risk of contracting Morbus Huntington is viewed as biological fate and thus treated as something for which a person cannot be held responsible.

\section{Critical paradoxes}

The call to distinguish genetic discrimination from other types of discrimination and subject it to special legislation has a paradoxical impact. The prohibition on the "unequal treatment" of people with an "abnormal" genetic constitution reinforces the cultural belief in the exceptional status of genetic factors, something which the legal regulation was supposed to counter in the first place. The analysis and critique of genetic discrimination itself relies on the phantasm that genes forms the "blueprint" for an individual and the "secret of life". ${ }^{64}$ In this way, the anti-discrimination legislation threatens to intensify the very problem it set out to solve. This brings us up against a key dilemma. ${ }^{65}$ On the one side, there are practices of genetic discrimination and people who suffer from these practices and, on the other, genetic essentialism is rejuvenated and reinforced by the academic and legal confirmation of the special role of genetic factors.

This dilemma by no means signifies that legal stipulations to protect people with genetic peculiarities are superfluous or even damaging. On the contrary, even if genetic information, seen scientifically, should be accorded no privileged role over non-genetic data, in social reality they quite obviously have a pronounced 
importance. ${ }^{66}$ In cultural terms, genes symbolize something fateful and immutable ${ }^{67}$, are considered "the most intimate biological property that we have" 68 and are thought to decisively influence the individual course of life ${ }^{69}$. Unlike other health risks, that are temporary, treatable, and can essentially be eliminated, genes are construed as the basis for a person's identity. He or she is said to "carry" or "possess" not only genetic risks, these are actually considered to be an integral part of the person's physical existence. ${ }^{70}$ If genetic factors are made responsible for a disease, then the person affected feels they are not controllable and are thus more threatening than if nongenetic reasons are cited. ${ }^{71}$ Equally, the risk of genetic illness cannot be separated from the history of eugenics, the cataloguing and murdering of people who were considered "genetically inferior", from a trans-generational notion of illness and the idea of "defective" or "poor" genes. ${ }^{72}$ As long as this cultural stereotype and historical prejudice persists, and people are disadvantaged or shown disrespect owing to their genetic peculiarities, it is imperative to legally protect them.

However, such legal protection must not result in genetic data being isolated form other (predictive) medical information. Genetic discrimination is the result of an increasing extension of the concept of illness and disability and the expansion of existing practices of contempt, stigmatization and exclusion. For this reason, the prohibition on genetic discrimination must necessarily be supplemented by profound institutional reforms and comprehensive regulations that more effectively protect persons already ill or disabled from social exclusion and disadvantage. ${ }^{73}$ That said, it is also necessary to rethink the analysis and critique of genetic discrimination with a view to its premises and goals. Otherwise we would run the risk of the distinction between genetic and non-genetic leading us to ignore the more fundamental question of the way (predictive) medical information is in general used to categorize persons, attribute characteristics and features to them, and exclude them from particular benefits. $^{74}$ In the absence of such dual self-enlightenment, the critique of genetic discrimination simply leads to a further "geneticization" of the body, illness and deviance.

\footnotetext{
${ }^{1}$ This article rests on work undertaken as part of a research project funded by the German Research Foundation and entitled "Genetic Diagnostics in the Risk Society", which ran at the Institut für Sozialforschung in Frankfurt/Main. Many of the ideas and much encouragement for this essay stem from discussions with members of the Genetic Screening Study Group in Boston as well as representatives of the Council for Responsible Genetics in Cambridge/Mass. I would, in particular, like to thank Joseph Alper, Jon Beckwith, Peter Conrad, Lisa N. Geller and Sujatha Byravan as well as Diane Paul and Sarah Jensen. I also gratefully acknowledge the help of Jeremy Gaines in translating the text and the useful comments that Susanne Krasmann, Sigrid Graumann and Ulrich Bröckling offered on the first version of this essay.

${ }^{2}$ See e.g. F. S. Collins, Shattuck Lecture - Medical and Societal Consequences of the Human Genome Project, in: New England Journal of Medicine. 1999; 341: 28-37.

${ }^{3}$ P. R. Billings, M. A. Kohn, M. de Cuevas, J. Beckwith, J. S. Alper \& M. R. Natowicz, Discrimination as a Consequence of Genetic Testing, in: American Journal of Human Genetics. 1992; 50: 476-482; L. N. Geller et al., Individual, Family, and Societal Dimensions of Genetic Discrimination: A Case Study Analysis, in: Science and Engineering Ethics. 1996; 2: 71-88; L. Low, S. Kind, T. Wilkie, Genetic discrimination in life insurance: empirical evidence from a cross sectional survey of genetic support groups in the United Kingdom, in: British Medical Journal. 1998; 317: 1632-1635; M. Otlowski, S. Taylor, K. K. Barlow-Stewart, Australian Empirical Study into Genetic Discrimination, in: Eubios. Journal of Asian and International Bioethics. 2002; 12: 164-167.
} 
${ }^{4}$ For an overview of the studies available to date on experience with genetic discrimination, see $\mathrm{T}$. Lemke/C. Lohkamp, Formen und Felder genetischer Diskriminierung. Ein Überblick über empirische Studien und aktuelle Fälle, in: Wolfgang van den Daele (ed.), Biopolitik, Wiesbaden: Verlag für Sozialwissenschaften; 2005: 45-70.

5 D. Nelkin, L. Tancredi. Dangerous Diagnostics. The Social Power of Biological Information, Chicago/London: University of Chicago Press; 1994, p. 176.

6 J. Rifkin, Genetische Diskriminierung. Eine neue Form des sozialen Vorurteils, in: Süddeutsche Zeitung, 29th june 2000.

7 " [...] genetic discrimination is defined as discrimination against an individual or against members of that individual's family solely because of real or perceived differences from the 'normal' genome of that individual. Genetic discrimination is distinguished from discrimination based on disabilities caused by altered genes by excluding, from the former category, those instances of discrimination against an individual who at the time of the discriminatory act was affected by the genetic disease" (Billings et al. op. cit. note 3, p. 477; see also M. R. Natowicz et al. Genetic Discrimination and the Law, in: American Journal of Human Genetics. 1992; 50: 465-475, here: p. 466).

${ }^{8}$ V. E. Lapham, C. Kozma, J. O. Weiss. Genetic Discrimination: Perspectives of Consumers, in: Science. 1996; 274: 621-624.

9 See also the comprehensive definition proposed by T. Neuer-Miebach. "Genetische Diskriminierung". In: CDU-Bundesgeschäftsstelle (ed.), Arbeitsmaterialien Bioethik, Berlin; 2001: 53-67, here: p. 54: "I term disadvantaging on the basis of a genetic predisposition that leads to disability and/or illness, or a genetically caused illness, a risk of disability or illness, genetic discrimination."

${ }_{10}$ Billings et al. op. cit. note 3; Geller et al. op. cit. note 3.

${ }^{11}$ M. A. Hall, S. S. Rich. Laws Restricting Health Insurers' Use of Genetic Information: Impact on Genetic Discrimination, in: American Journal of Human Genetics. 2000; 66: 293-307; here: p. 294 ; D. Hellman. What Makes Genetic Discrimination Exceptional? in: American Journal of Law \& Medicine. 2003; 29: 77-116, here: p. 86.

William Nowlan and Philip R. Reilly also champion a narrow interpretation of genetic discrimination and consider the problem's importance to be vastly exaggerated (W. J. Nowlan. A Scarlet Letter or a Red Herring? Genetic Discrimination Is of Little Concern Compared With Existing US Healthcare Problems, in: Nature. 2003; 421 (6921): 313; P. R. Reilly. Genetic Discrimination, in: Clarissa Long (ed.), Genetic Testing and the Use of Information, Washington DC: AEI Press; 1999: 106-132.

12 Deutscher Bundestag. Schlussbericht der Enquete-Kommission "Recht und Ethik in der modernen Medizin", Opladen: Leske und Budrich; 2002, p. 288.

${ }^{13}$ For a brief juxtaposition of the two poles in the discussion, see A. Somek. Genetic Discrimination, in: Society. 2003; 40 (6): 35-43; here: p. 37-39.

14 C. S. Diver, J. M. Cohen. Genophobia: What Is Wrong With Genetic Discrimination? in: University of Pennsylvania Law Review. 2001; 149: 1439-1482.

For example, the authors hold that in the case of employment relationships the use of genetic investigative techniques could lead to employees who are unproductive or prone to illness not being employed in the first place and thus to costs being saved: "Hiring or promoting an under-qualified or under-productive worker is inevitably costly to the employer. [...] Monitoring and corrective action require investment in supervision, and often require changes in production design or scheduling. In the meantime, the under-performing worker inflicts on the organization both demoralization costs and the opportunity costs of foregone output. For these reasons, it is almost always in the employer's interest to establish better ex ante screening mechanisms so as to select workers who will require less supervision and corrective action." (Diver/Cohen op. cit., p. 1461).

15 The following considerations are based primarily on the results of the empirical study I undertook on experiences people affected by Huntington's Disease have had of genetic discrimination (T. Lemke. Genetische Diskriminierung in Deutschland - Eine explorative Studie am Beispiel der HuntingtonKrankheit, in: Soziale Welt. 2005; 56: 417-440).

${ }^{16}$ L. Wess. Eugenik im Zeitalter der Gentechnologie - Vom Zwang zur freiwilligen Inanspruchnahme, in: Anne-Dore Stein (ed.), Lebensqualität statt Qualitätskontrolle menschlichen Lebens, Berlin: Marhold; 1992: 65-82. 
17 A. Waldschmidt. Das Subjekt in der Humangenetik. Expertendiskurse zu Programmatik und Konzeption der genetischen Beratung 1945-1990, Münster: Verlag Westfälisches Dampfboot; 1996: 275.

18 J. Habermas. Die Zukunft der menschlichen Natur. Auf dem Weg zu einer liberalen Eugenik? Frankfurt am Main: Suhrkamp; 2001.

19 T. Degener, S. Köbsell. "Hauptsache, es ist gesund"? Weibliche Selbstbestimmung unter humangenetischer Kontrolle, Hamburg: Konkret Verlag; 1992: 67-92.

${ }^{20}$ P. Weingart. Politik und Vererbung: Von der Eugenik zur modernen Humangenetik, in: Eckart Voland (ed.), Fortpflanzung: Natur und Kultur im Wechselspiel. Versuch eines Dialogs zwischen Biologen und Sozialwissenschaftlern, Frankfurt am Main: Suhrkamp; 1992: 28-50; here: p. 45-49.

${ }^{21}$ See the distinction made by the German Government Enquiry Commission on "Right and Ethics in Modern Medicine": "Direct discrimination means a morally not justified unequal treatment or ostracization of persons by other persons or institutions. This covers, for example, discrimination of employees or insured persons or disabled persons on the basis of a genetic test. Indirect discrimination means the social values and norms that express a disrespect for certain people. This would include the establishment of social norms such as 'a life worth living' owing to chronic illness or disability" (Deutscher Bundestag. op. cit. note 12, p. 57).

Deborah Hellman's “expressivist argument” puts forward a similar distinction (op. cit. note 11, p. 108).

${ }^{22}$ Cf. M. Konrad. From Secrets of Life to the Life of Secrets: Tracing Genetic Knowledge as Genealogical Ethics in Biomedical Britain, in: Royal Anthropological Institute. 2003; 9: 339-358.

23 T. Neuer-Miebach, op. cit. note 9, p. 56-59; S. Volz. Diskriminierung von Menschen mit Behinderung im Kontext von Präimplantations- und Pränataldiagnostik, in: S. Graumann, K. Grüber (eds.), Medizin, Ethik und Behinderung, Frankfurt am Main: Mabuse Verlag; 2003: 72-88.

${ }^{24}$ S. M. Wolf. Beyond 'genetic discrimination': Toward the broader harm of geneticism, in: Journal of Law Medicine \& Ethics. 1995; 23: 345-353; L. B. Andrews. Future Perfect. Confronting Decisions About Genetics, New York: Columbia University Press; 2001: 77-97.

${ }^{25}$ T. Duster. Backdoor to Eugenics, New York/London: Routledge; 1991: 24-28; 45-51.

${ }^{26}$ European Commission (ed.). Ethical, legal and social aspects of genetic testing: research, development and clinical applications, Brussels: EC; 2004: 50.

On the increasing focus on the category of "race" in genome research see H. Bradby. Genetics and racism, in: T. Marteau, M. Richards (eds.), The troubled helix: social and psychological implications of the new human genetics, Cambridge: Cambridge UP; 1996: 295-316; G. T. Ellison, T. H. George, I. Rees. Social identities and the 'new genetics': scientific and social consequences, in: Critical Public Health. 2002; 12: 265-282; P. Aldhous. Geneticist fears "race-neutral" studies will fail ethnic groups, in: Nature. 2002; 418: 355-356; J. S. Alper, J. Beckwith. Genetics, Race, and Ethnicity, in: J. S. Alper et al. (eds.), The Double-Edged Helix. Social Implications of Genetics in a Diverse Society, Baltimore/London: John Hopkins UP; 2002: 175-196; Nature Genetics 2004: 'Race' and the human genome, in: Nature Genetics Supplement 36 (november 2004).

The danger of a linkage of genetic discrimination and racism is obviously not restricted to the clinical domain. Racist discrimination can arise from the use of genetic data in criminal justice, something the inventor of the "genetic finger-print", Sir Alec Jeffreys, points to. Jeffreys expressed concern given the ever more extensive DNA database run by the Metropolitan Police Force that now holds 2.5 million data sets. They include not only DNA samples from convicts, but also genetic information on suspects. "For a start, we are now putting not just criminals but suspects in our database, and this is clearly very highly discriminatory. If you go to certain places such as South London, you will get suspects who are predominantly black. Similarly you will get a lot of Asian suspects in Birmingham.” Jeffreys concludes that the national database will be filled with a large number of blacks and persons of Asian descent who have not been found guilty of a crime, but of whom one suspects that they will in the future commit such (cf. R. McKie. Inventor warns over abuse of DNA data, in: Observer, 8th august 2004; see also S. Cole. Suspect Identities. A History of Fingerprinting and Criminal Identification, Cambridge, MA \& London: Harvard University Press; 2001: 287-311; D. Wasserman, R. Wachbroit. Genetics and Criminal Behavior, Cambridge: Cambridge University Press; 2001. 
${ }^{27}$ See the statement of Albert Fromme, Director of the Medical Section of the Organization Committee in Münster handling the Volleyball World Championships: "For the sportswomen, this is a form of discrimination. Men do not have to prove their masculinity" (quoted from Sport 1. Fromme: "Männer müssen ihre Männlichkeit nicht beweisen", in: www.sport1.de/coremedia/generator/ www.sport1.de/ Sportarten/Mehr/Volleyball (access date: 4th september 2002).

See also J. L. Simpson, A. Ljungqvist, M. A. Ferguson-Smifh, A. de la Chapelle, L. J. Elsas, A. A. Ehrhardt, M. Genel, E.A. Ferris, A. Carlson. Gender Verification in the Olympics., in: Jama - Journal of the American Medical Association. 2000; 284 (12): 1568-1569; B. D. Dickinson, M. Genel, C. B. Robinowitz, P. L. Turner, G. L. Woods. Gender Verification of Female Olympic Athletes. Medicine and Science, in: Sports and Exercise. 2002; 34: 1539-1542.

${ }^{28}$ Wolf, op. cit. note 24 .

${ }^{29}$ J. S. Alper, J. Beckwith. Distinguishing Genetic from Nongenetic Medical Tests: Some Implications for Antidiscrimination Legislation, in: Science and Engineering Ethics. 1998; 4: 141-150.

${ }^{30}$ T. H. Murray. Genetic Exceptionalism and "Future Diaries": Is Genetic Information Different from Other Medical Information? in: M. A. Rothstein (ed.), Genetic Secrets. Protecting Privacy and Confidentiality in the Genetic Era, New Haven/London: Yale University Press; 1997: 60-73; D. B. Paul. What Is a Genetic Test, and Why Does It Matter? in: Endeavour. 1999; 23: 159-161, here: p. 160; European Commission, op. cit. note 26, p. 44.

${ }^{31}$ See on the following J. Beckwith, J. S. Alper op. cit. note 29, p. 143-144.

32 G. Feuerstein, R. Kollek. Risikofaktor Prädiktion. Unsicherheitsdimensionen diagnostischer Humanexperimente am Beispiel prädiktiver Brustkrebstests, in: L. Honnefelder/C. Streffer (eds.), Jahrbuch für Wissenschaft und Ethik, 5. Berlin: De Gruyter; 2000: 91-115; T. Lemke. Veranlagung und Verantwortung. Genetische Diagnostik zwischen Selbstbestimmung und Schicksal, Bielefeld: transcript Verlag; 2004: 70-76.

${ }^{33}$ A. Kerr. (Re)Constructing Genetic Disease: The Clinical Continuum between Cystic Fibrosis and Male Infertility, in: Social Studies of Science. 2000; 30: 847-894; H. van den Boer-van den Berg, A. A. Maat-Kievit. The whole truth and nothing but the truth, but what is the truth? in: Journal of Medical Genetics. 2001; 38: 39-42.

${ }^{34}$ R. Hubbard, R. C. Lewontin. Pitfalls of genetic testing, in: The New England Journal of Medicine. 1996; 334, S. 1192-1194; U. Wolf. Identical mutations and phenotypic variation, in: Human Genetics. 1997; 100: 305-321.

${ }^{35}$ Murray op. cit. note 30, p. 64; R. L. Zimmern. Genetic Testing: a Conceptual Exploration, in: Journal of Medical Ethics. 1999; 25: 151-156; European Commission op. cit. note 26, p. 44.

${ }^{36}$ Murray op. cit. note 30. p. 65.

${ }^{37}$ While today a hard-line genetic determinism is less accepted in genome research, we can still observe "the narrative of enlightened geneticization", that presents current genetic thinking as nonreductionist, grants a role for non-genetic factors while at the same time prioritizing genetic explanations to behavior or disease (A. Hedgecoe. Schizophrenia and the Narrative of Enlightened Geneticization, in: Social Studies of Science. 2001; 31: 875-911; T. Lemke. Mutationen des Gendiskurses: Der genetische Determinismus nach dem Humangenomprojekt, in: Leviathan. Zeitschrift für Sozialwissenschaft. 2002; 30: 400-425).

${ }^{38}$ E. F. Keller. The century of the gene, Cambridge, MA/London: Harvard UP; 2000; E. F. Keller. Making Sense of Life. Explaining Biological Development with Models, Metaphors, and Machines, Cambridge, MA/London: Harvard UP; 2002.

${ }^{39}$ Developmental systems theory shows that a rigid juxtaposition of culture and nature does not suffice to explain biological processes. It assumes that biological characteristics refer by no means to a culturally-independent and trans-historical essential core; they are the result, not the cause of developmental processes within a complex system, in which social and psychological factors also play a key role. This research program thus severs any ties with biological or social variants of determinism (cf. S. Oyama. The Ontology of Information, Duke University Press; 2000; see also A. Fausto-Sterling. The problem with sex/gender and nature/nurture, in: S. J. Williams, L. Birke, G. A. Bendelow (eds.), Debating Biology. Sociological reflections on health, medicine and society, New York/London: Routledge; 2003: 123-132).

${ }^{40}$ I shall return to this point below. 
${ }^{41}$ Murray op. cit. note 30, p. 65-66; J. S. Geetter. Coding for Change: the Power of the Human Genome to Transform the American Health Insurance System, in: American Journal of Law \& Medicine. 2002; 28: 1-76.

On the relationship between health and responsibility, see S. J. Reiser. Responsibility for Personal Health - a Historical Perspective, in: Journal of Medicine and Philosophy. 1985; 10: 7-17; A. M. Brandt, P. Rozin (eds.). Morality and Health, New York \& London: Routledge; 1997.

${ }^{42}$ See L. E. Kay. Who wrote the book of life? A history of the genetic code, Stanford: Stanford University Press; 2000; L. Moss. What genes can't do, Cambridge/MA und London: MIT Press; 2003.

${ }^{43}$ E. J. Yoxen. Constructing Genetic Diseases, in: T. Duster, K. Garrett (eds.), Cultural Perspectives on Biological Knowledge, Norwood/NJ: Ablex Publishing Corporation; 1984: 41-62; T. Lemke. Molekulare Medizin? Anmerkungen zur Ausweitung und Redefinition des Konzepts der genetischen Krankheit, in: Prokla. Zeitschrift für kritische Sozialwissenschaft. 2003; 33: 471-492.

Murray talks of a "two-bucket theory of disease" that in the final instance rests on the erroneous assumption that we can medically distinguish clearly between genetic and non-genetic illnesses or factors for illness: "According to this model, there are two buckets - one labeled 'genetic', the other labeled 'nongenetic' - and we should be able to toss every disease and risk factor into one of the two. So, Huntington disease goes into the 'genetic' bucket and getting run over by a truck goes into the 'nongenetic' one. But many diseases and risks don't fit neatly into either bucket. Take breast cancer. Some cases of breast cancer have strong genetic roots, but others have no clear genetic connection. For that matter, not every woman with a mutated BRCA1 gene will develop breast cancer. And some apparent risk factors have little or no link to genetics. Similar complexity exists for heart disease: cholesterol is a risk factor, and one's cholesterol level can be modified by diet, exercise, and other factors; but our genes have as much or more to do with the level of cholesterol circulating in our blood as our environment or behavior. Into which bucket, then, should we toss breast cancer? Heart disease? Cholesterol level?" (Murray, op. cit. note 30, p. 67-68).

44 Zimmern op. cit. note 35; J. Schmidtke, K. Sperling. Genetische Tests auf dem Teststand, in: Zeitschrift für Biopolitik. 2003; 2: 39-47.

45 Alper/Beckwith, op. cit. note 29, p. 145. J. Beckwith, J. S. Alper. Reconsidering Genetic Antidiscrimination Legislation, in: Journal of Law, Medicine and Ethics. 1998; 26: 205-210, here: p. 207. Zimmern has pointed out that the concept of genetic information possesses two mutually contradictory meanings: "First it may be regarded as information about the genetic constitution of individuals, their genes or chromosomes, and their inheritance. Second, and by contrast, genetic information may be taken to refer to any information from which we may infer knowledge about the genetic constitution of individuals" (op. cit. note 35 , p. 152).

${ }^{46}$ Paul, op. cit. note 30. On the history of PKU see D. B. Paul. PKU Screening: Competing Agendas, Converging Stories. in: D. B. Paul, The Politics of Heredity. Essays on Eugenics, Biomedicine, and the Nature-Nurture Debate, Albany: State University of New York; 1998: 173-186.

${ }^{47}$ Billings et al., op. cit. note 3 .

48 See, for example, M. Rothblatt. Unzipped Genes. Taking charge of baby-making in the new millenium, Philadelphia: Temple University Press; 1997: 157: "If we have a genomic predisposition to a particular condition that interferes with our job ability, then it is wrong to deny that job until the condition manifests itself."

${ }^{49}$ G. Wolbring. Folgen der Anwendung genetischer Diagnostik für behinderte Menschen, Berlin: Gutachten erstellt im Auftrag der Enquete-Kommission des Deutschen Bundestages "Recht und Ethik der modernen Medizin“; 2001: 87.

${ }^{50}$ F. Mechan-Schmidt. Teacher protests at gene bias, in: Times Educational Supplement, $14^{\text {th }}$ november 2003; J. Burgermeister. Teacher was refused job because relatives have Huntington's disease, in: British Medical Journal. 2003; 327: 827-a; G. Traufetter. Geisel der eigenen Gene, in: Der Spiegel. 2003, no. 42: $216-218$

${ }^{51}$ Huntington's Disease is a neurodegenerative illness that usually breaks out in the fourth or fifth decade of the person's life. It is triggered by an increased repetition of a certain triplet (the sequences of three nuclear bases cytosine, adenine, guanine: $\mathrm{CAG}$ ) in the Huntington gene, which is located on the short arm of Chromosome 4 (cf. H. W. Lange. Morbus Huntington - Klinik, Diagnose und Therapie, in: Psycho. 2002; 28: 479-486).

52 Frankfurter Rundschau. Erblich belastete Lehrerin wird Beamtin, in: Frankfurter Rundschau, 3rd August 2004; Ruling of the Darmstadt Administrative Court of June 24, 2004, AZ 1 E 470/04 (3). 
${ }^{53}$ Frankfurter Rundschau. Zu dick für Beamtenjob, in: Frankfurter Rundschau, 3rd june 2004.

${ }^{54}$ Alper/Beckwith, op. cit. note 29, p. 147; Zimmern, op. cit. note 35, p. 153.

${ }^{55}$ See Geetter, op. cit. note 41.

${ }^{56}$ A legal prohibition on genetic discrimination would probably lead to further commercialization of the genetic diagnostics sector or enable this to happen in the first place. For example, William Rice, President and Medical Director of myDNA, the US provider of genetic diagnostics, expressly champions a federal anti-discrimination law, as he believes most citizens will in the absence of protection of their genetic privacy avoid genetic screening in order to prevent discrimination in the place of work and in insurance contracts (Yahoo Financial News. My DNA Media Endorses Passage of the Genetic Non-Discrimination Act of 2003, in: Yahoo Financial News, $21^{\text {st }}$ june 2004.). In Germany, the Diagnostics Industry Association issued a similar statement in a communiqué that advocates supporting the planned genetic diagnostics law (see K.-P. Görlitzer. Gentest-Gesetz nach Wünschen von Kassen, Forschern und Firmen, in: Bioskop. 2004; 7 (28): 8-9).

${ }^{57}$ Cf. E. R. Shell. The Hungry Gene. The Science of Fat and the Future of Thin, New York: Atlantic Monthly Press; 2002; J. Hebebrand. Mehr Übergewicht - mehr Krankheiten? Genetische Ursachen der Übergewichtigkeit werden erforscht, in: GenomXPress. 2004; no. 4: 19-21.

${ }^{58}$ See on this also Wolf, op. cit. note 24.

${ }^{59}$ This argument is also typical of many scholarly articles that critically focus on practices of genetic discrimination. See, for example, L. Gostin. Genetic Discrimination: The Use of Genetically Based Diagnostic and Prognostic Tests by Employers and Insurers, in: American Journal of Law \& Medicine. 1991; 17 (no. 1+2): 109-144, p. 110-1: "Prejudice, alienation and exclusion often accompany genetically related diseases even though, by definition, the condition is neither subject to the person's control, nor the result of willful behavior.” Likewise, Rothblatt, op. cit. note 48: 157: „Genomic discrimination is wrong because it categorizes us on the basis of biology over which we have no control and which is irrelevant for any social, economic, or legal purpose."

${ }^{60}$ Bundesministerium für Gesundheit und Soziales. Begründung zum Diskussionsentwurf "Gesetz über genetische Untersuchungen bei Menschen”, Berlin; 200: 16. For a similar point see the statement of the German Minister of Justice who holds that genes are "the most valuable good that a human being possesses." (cited by C. Schwägerl. Gentests. Prinzip Selbstbestimmung, in: Frankfurter Allgemeine Zeitung, 14th Januar 2005: 4).

${ }^{61}$ Diver/Cohen, op. cit. note 14, p. 1451-1452.

${ }^{62}$ See also Beckwith/Alper, op cit. note 45, p. 208: "This rationale seems to carry with it the invidious implication that we are responsible for our nongenetic diseases."

${ }^{63}$ H. Kühn. "Selbstverantwortung" in der Gesundheitspolitik, in: Jahrbuch für kritische Medizin. 1998; no. 30: 7-20; M. Bause. Guter Rat ist teuer - humangenetische Beratung unter den Bedingungen der Marktindividualisierung, in: J. Schmidtke (ed.), Guter Rat ist teuer. Was kostet die Humangenetik, was nutzt sie? Munich \& Jena: Urban \& Fischer; 2000: 96-106.

${ }^{64}$ Ingrid Schneider points to a similar problem in the context of the debate on patenting human genes: "However, because critics and the persons affected assert that the patenting robs them of their innermost being or 'identity', they reproduce and confirm a genetic determinism and essentialism that erroneously reduces human existence to DNA structures" (I. Schneider. Patente Argumente? in: Bioskop. 1999; no. 8: 14-15, p. 15).

${ }^{65}$ See, among others, Beckwith/Alper, op. cit. note 45, p. 208.

${ }^{66}$ This argument is explained in detail by D. Hellman, op. cit. note 11, p. 79: "This article will develop the argument that because the social meaning of treating people differently on the basis of their genetic make-up is different from the social meaning of discrimination on the basis of health or illness, special legislation is warranted to prohibit genetic discrimination"; see also Murray, op. cit. note 30, p. 71.

${ }^{67}$ See the critical analysis in D. Nelkin, S. M. Lindee. The DNA Mystique. The Gene As a Cultural Icon, New York: W. H. Freemann \& Co; 1995; J. van Dijck. Imagenation. Popular Images of Genetics, New York: New York University Press; 1998.

${ }^{68}$ J. Schmidtke. Vererbung und Ererbtes - Ein humangenetischer Ratgeber, Reinbek: Rowohlt; 1997: 13.

${ }^{69}$ T. Burnham, J. Phelan. Mean Genes. From Sex to Money to Food: Taming our Primal Instincts, Cambridge/MA: Perseus Publishing; 2000; P. Little. Genetic Destinies, Oxford: Oxford University Press; 2002. 
70 A. M. Kavanagh, D. H. Broom. Embodied Risk: My Body, Myself? in: Social Science \& Medicine. 1998; 46: 437-444.

${ }^{71}$ V. Senior, T. M. Marteau, T. J. Peters. Will genetic testing for predisposition for disease result in fatalism? A qualitative study of parents responses to neonatal screening for familial hypercholesterolaemia, in: Social Science \& Medicine. 1999; 48: 1857-60.

${ }^{72}$ N. Holtzman, M. A. Rothstein. Invited Editorial - Eugenics and Genetic Discrimination, in: American Journal of Human Genetics. 1992; 50: 457-459; D. J. Kevles. In the name of eugenics: genetics and the uses of human heredity. Cambridge, MA/London: Harvard University Press; $1995 ; \mathrm{H}$. Markel. The Stigma of Disease - Implications of Genetic Screening, in: American Journal of Medicine. 1992; 93: 209-215; P. Weingart, J. Kroll, K. Bayertz. Rasse, Blut und Gene. Geschichte der Eugenik und Rassenhygiene in Deutschland, Frankfurt am Main: Suhrkamp; 1992.

73 Alper/Beckwith op. cit. note 29, p. 148; Beckwith/Alper, op. cit. note 45, p. 209; Geetter, op. cit. note 41.

${ }^{74}$ See Wolf op. cit. note 24. 